\title{
Potensi Buah Embam (Mangifera odorata Griff.) yang Jatuh untuk Mendukung Kelangsungan Hidup Serangga (Insecta)
}

\author{
Ari Sugiarto \\ Email: sugiartoari13@gmail.com
}

\begin{abstract}
Abstrak
Embam (Mangifera odorata) merupakan salah satu spesies mangga (Mangifera spp.) yang memiliki aroma yang khas. Beberapa spesies lalat buah lebih tertarik meletakkan telurnya pada buah mangga dibanding buah lainnya. Tidak menutup kemungkinan beberapa spesies serangga memanfaatkan buah embam yang jatuh untuk meletakkan telur atau sebagai sumber makanan. Perlu dilakukan penelitian mengenai potensi buah embam yang jatuh untuk mendukung kelangsungan hidup serangga. Penelitian ini dilakukan pada bulan November 2018 dengan mengamati buah embam yang jatuh di bawah pohonnya untuk melihat serangga apa saja yang terdapat pada buah tersebut dan menganalisis manfaatnya bagi serangga tersebut. Ditemukan 6 spesies serangga dari total 6 famili dan 2 order pada buah embam yang jatuh. Spesies serangga dari ordo Diptera paling banyak ditemukan dengan jumlah total 5 spesies dari 5 famili. Spesies serangga dari ordo Hymenoptera yang ditemukan hanya 1 spesies. Perbedaan kematangan dan kondisi buah embam mempengaruhi spesies serangga yang ditemukan. Pada buah embam yang matang dapat bermanfaat sebagai sumber makanan bagi serangga, sedangkan pada buah embam yang busuk dapat bermanfaat bagi serangga untuk meletakkan telurnya.
\end{abstract}

Kata Kunci: Buah Embam, Diptera, Hymenoptrea, Kelangsungan Hidup Serangga

\section{Pendahuluan}

Embam (Mangifera odorata) merupakan salah satu spesies mangga (Mangifera spp.) yang memiliki aroma yang khas. Berdasarkan penelitian Ariffin et al. (2015), Mangifera odorata berkerabat dekat dengan mangga harumanis, mangga mahathir, dan mangga apel. Menurut Orwa et al. (2009), nama lokal Mangifera odorata di beberapa negara seperti Inggris (saipan mango), Filipina (uani, kuwini), Francis (manguier, mangue odorante), Indonesia (kuweni, kaweni, bembem), Malaysia (wani, huani) dan Thailand dikenal dengan nama Ma-mut dan mamuang chingreet.

Masyarakat di wilayah Sumatera Selatan biasa mengenal Mangifera odorata dengan nama embam. Populasi embam diwilayah Sumatera Selatan tergolong banyak. Terkhusus di Kecamatan Sirah Pulau Padang, Kabupaten Ogan Komering Ilir pohon embam ini dapat ditemukan dengan mudah karena populasinya yang banyak.
Dimusim panen, buah embam dapat diperoleh dengan mudah dan nilai ekonomis dari buah ini tergolong rendah dibandingkan dengan buah mangga lainnya. Bahkan untuk buah embam yang jatuh hanya dibiarkan saja. Buah embam yang jatuh ini dapat bermanfaat untuk mendukung kelangsungan hidup dari serangga.

Berdasarkan penelitian dari Dias et al. (2018), lalat buah dari spesies Anastrepha fraterculus meletakkan telurnya lebih banyak pada buah mangga dibanding pada buah pepaya, jambu biji, jeruk, dan jeruk keprok. Menurut Rossetto et al. (2006), beberapa varietas mangga memiliki ketahan yang berbeda terhadap spesies lalat buah.

Tidak menutup kemungkinan beberapa spesies serangga memanfaatkan buah embam yang jatuh untuk meletakkan telur atau sebagai sumber makanan. Perlu dilakukan penelitian mengenai potensi 
buah embam yang jatuh untuk mendukung kelangsungan hidup serangga. Hasil dari penelitian ini dapat memberikan masukkan mengenai manfaat kaitan antara buah embam terhadap beberapa spesies serangga dan dapat menjadi alternatif perangkap buah untuk memancing kahadiran spesies serangga tertentu.

\section{Metode Penelitian}

Penelitian ini dilakukan pada bulan November 2018 dengan mengamati buah embam yang jatuh di bawah pohonnya untuk melihat serangga apa saja yang terdapat pada buah tersebut dan menganalisis manfaatnya bagi serangga tersebut. Pemilihan pohon embam yang digunakan untuk pengamatan yaitu memiliki kriteria telah berbuah matang. Pengamatan ini dilakukan di beberapa pohon embam yang terdapat buahnya yang jatuh. Lokasi pemilihan pohon embam ini berada pada kawasan Desa Serdang Menang, Kecamatan Sirah Pulau Padang, Kabupaten Ogan Komering Ilir. Pemilihan lokasi ini berdasarkan pertimbangan pada saat melakukan penelitian, buah embam mudah untuk ditemukan saat musim panen pada bulan Oktober sampai dengan November. Dilakukan pengamatan terhadap perbedaan buah matang, mentah, dan busuk terhadap spesies serangga yang ditemukan. Dilakukan juga pengamatan kondisi buah yang kulitnya sudah terbuka dan buah yang masih utuh terhadap spesies serangga yang ditemukan. Pengamatan ini dilakukan secara visual dan didokumentasika dengan bantun camera. Identifikasi spesies serangga yang didapatkan dilakukan dengan mencocokan spesies serangga yang sudah teridentifikasi.

\section{Hasil dan Pembasan}

Berdasarkan pengamatan yang telah dilakukan, didapatkan hasil yaitu:

Tabel 1. Spesies serangga yang ditemukan pada buah embam yang jatuh

\begin{tabular}{llll}
\hline Ordo & Famili & Genera & Spesies \\
\hline Diptera & Calliphoridae & Chrysomya & Chrysomya megacephala \\
\hline & Drosophilidae & Drosophila & Drosophila melanogaster \\
\hline & Micropezidae & Micropeza & Micropeza sp. \\
\hline & Muscidae & Musca & Musca domestica \\
\hline Hymenoptera & Fephritidae & Bactrocera & Bactrocera dorsalis \\
\hline
\end{tabular}

Ditemukan 6 spesies serangga dari total 6 famili dan 2 order pada buah embam yang jatuh. Spesies serangga yang ditemukan yaitu Chrysomya megacephala (Calliphoridae), Drosophila melanogaster (Drosophilidae), Micropeza sp. (Micropezidae), Musca domestica (Muscidae), Bactrocera dorsalis (Tephritidae), dan Tapinoma sp. (Formicidae). Spesies serangga dari ordo Diptera paling banyak ditemukan dengan jumlah total 5 spesies dari 5 famili. Spesies serangga dari ordo Hymenoptera yang ditemukan hanya 1 spesies yaitu Tapinoma sp.
Tidak ditemukan spesies serangga apapun pada buah embam yang masih mentah. Ditemukan Bactrocera dorsalis pada buah embam yang matang dan pada buah embam yang busuk ditemukan Micropeza sp. Buah embam yang matang dan mentah dapat dibedakan dengan mencium aromanya, buah yang matang akan mengeluarkan aroma. Tidak adanya spesies serangga yang ditemukan pada buah embam yang mentah ini diperkirakan buah embam yang mentah tidak mengeluarkan aroma yang dapat memancing kehadiran spesies serangga tertentu. 


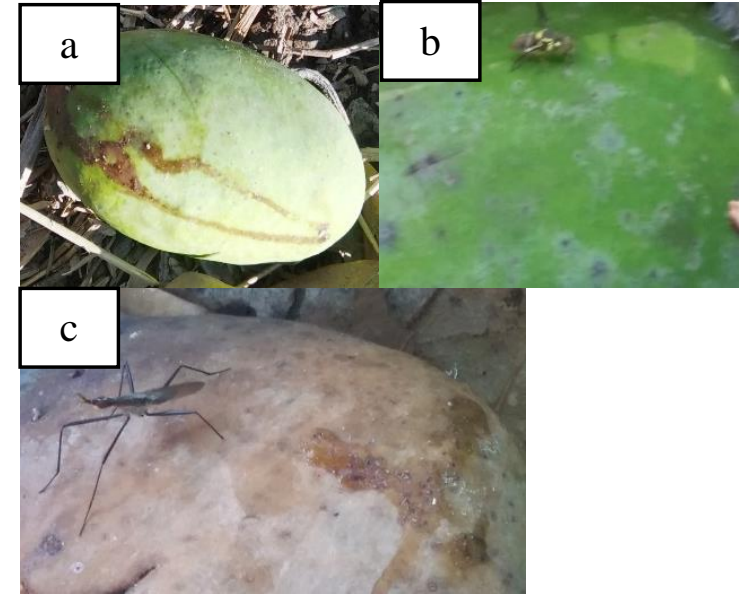

Gambar 1. a. Buah embam mentah, b. Buah emabam matang dan Bactrocera dorsalis, c. Buah embam busuk dan Micropeza sp.

Spesies serangga yang ditemukan pada buah embam yang terbuka dan mulai membusuk yaitu Bactrocera dorsalis, Chrysomya megacephala, Drosophila melanogaster, dan Musca domestica. Serangga yang ditemukan pada buah embam yang busuk ini diduga menjadikannya sebagai media untuk meletakkan telurnnya. Dalam beberapa waktu, telur ini akan menjadi larva. Menurut Dias et al. (2018), beberapa spesies lalat buah lebih tertarik meletakkan telurnya pada buah mangga. Menurut Duarte et al. (2013), kepadatan substrat makanan mempengaruhi kelangsungan hidup dari larva serangga

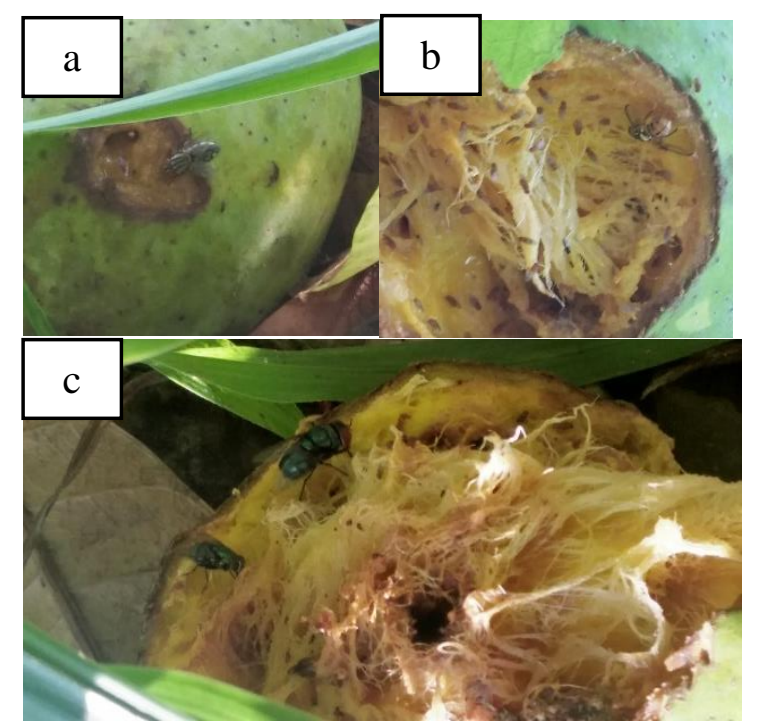

Gambar 2. Spesies serangga yang ditemukan pada buah embam yang terbuka dan mulai membusuk yaitu: a.Musca domestica, b. Bactrocera dorsalis dan Drosophila melanogaster, dan c. Chrysomya megacephala.

Spesies serangga yang ditemukan pada buah embam yang matang dan terbuka yaitu Bactrocera dorsalis, Chrysomya megacephala, Micropeza sp., dan Tapinoma sp. Spesies serangga yang ditemukan pada buah embam yang matang ini diduga menjadikan buah embam yang matang ini sebagai salah satu sumber makanannya. Menurut Sugiarto (2018), salah satu spesies semut yang dapat ditemukan di Desa Serdang Menang, Kecamatan Sirah pulau Padang, Kabupaten Ogan Komering Ilir yaitu Tapinoma sp. dan memancing kahadirannya dapat dilakukan dengan menggunakan minyak kelapa.

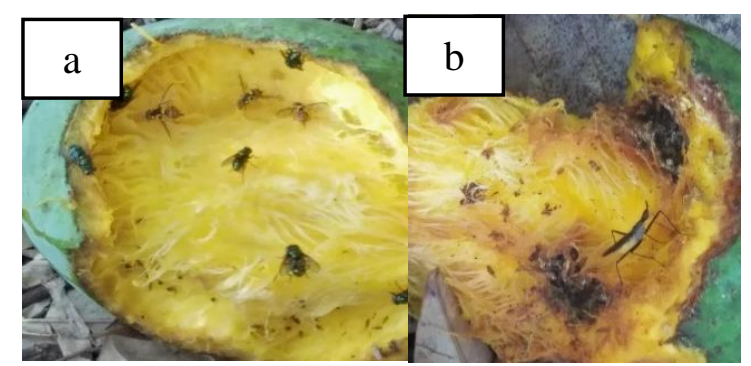

Gambar 3. Spesies serangga yang ditemukan pada buah embam yang matang dan terbuka yaitu: a. Bactrocera dorsalis dan Chrysomya megacephala, b. Micropeza sp. dan Tapinoma sp.

Spesies serangga yang ditemukan pada kulit buah embam yaitu Crysomya megacephala dan Musca domestica, sedangkan spesies serangga yang ditemukan pada biji buah embam yaitu Micropeza sp. 


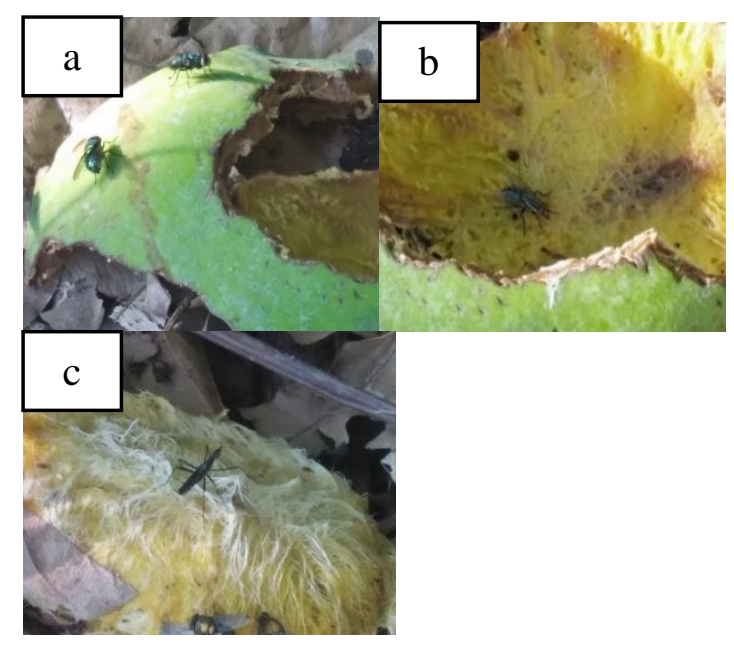

Gambar 4. Spesies serangga yang ditemukan pada kulit dan biji buah embam yaitu: a. Chrysomya megacephala, $\mathrm{b}$. Musca domestica, c. Micropeza $\mathrm{sp.}$

\section{Kesimpulan}

Buah embam yang jatuh dapat mendukung kelangsungan hidup dari beberapa spesies serangga dikarenakan buah embam yang jatuh ini dapat menjadi sumber makan dan sebagai media untuk meletakkan telur beberapa spesies serangga. Perbedaan kematangan dan kondisi buah embam juga mempengaruhi spesies serangga yang ditemukan. Pada buah embam yang matang dapat bermanfaat sebagai sumber makanan bagi serangga, sedangkan pada buah embam yang busuk bermanfaat bagi serangga untuk meletakkan telurnya.

\section{Daftar Pustaka}

Ariffin, Z., Muhammad, S. M. S., Salma, I., dan Nuradni, H. 2015. Genetic Diversity of Selected Mangifera Species Revealed by Inter Simple Sequence Repeats Markers. International Journal of Biodiversity. 1-8.
Dias, N.P., D.E. Nava, M.S. Garcia, F.F. Silva, dan R.A. Valgas. 2018. Oviposition of Fruit Fies (Diptera: Tephritidae) and its Relation with the Pericarp of Citrus Fruits. Brazilian Journal of Biology. 78(3): 443-448.

Duarte, J.L.P., Rodrigo, F.K., dan Paulo, B.R. 2013. Interaction Between Musca domestica L. and its Predator Muscina stabulans (Fallén) (Diptera, Muscidae): Effects of Prey Density and Food Source Abundance. Revista Brasileira de Entomologia. 57(1): 55-58.

Orwa, C., A. Mutua, Kindt, R., Jamnadass, R., dan S. Anthony. 2009. Agroforestree Database: a tree reference and selection guide version $4.0 \quad$ (Online). http://www.worldagroforestry.org /sites/treedbs/treedatabases.asp. Diakses pada 20 November 2018.

Rossetto, C.J., N. Bortoletto, J.M.M. Walder, T. de A. Mastrângelo, C.R.L. Carvalho, J.V. de Castro, A.C. de Q. Pinto, dan A.L. Cortelazzo. 2006. Mango Resistance to Fruit Flies. II Resistance of the Alfa Cultivar. Proceedings of the 7th International Symposium on Fruit Flies of Economic Importance di Salvador, Brazil.

Sugiarto, A. 2018. Utilization of Coconut Oil (Cocos nucifera L.) for Provoke the Presence of Ants (Hymenoptera: Fromicidae). (Online).

https://doi.org/10.31220/osf.io/45 gtj. Diakses pada 20 November 2018. 